Original Article

\title{
Fixation of pfcrt chloroquine resistance alleles in Plasmodium falciparum clinical isolates collected from unrest tribal agencies of Pakistan
}

\author{
Fixação de alelos de resistência à cloroquina pfcrt em isolados clínicos de Plasmodium \\ falciparum coletados de agitações de agências tribais do Paquistão
}

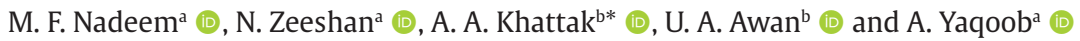 \\ ${ }^{a}$ Department of Biochemistry \& Biotechnology, University of Gujrat, Gujrat, Punjab, Pakistan \\ bDepartment of Medical Laboratory Technology, The University of Haripur, Haripur, Khyber Pakhtunkhwa, Pakistan
}

\begin{abstract}
Plasmodium falciparum resistance to Chloroquine (CQ) is a significant cause of mortality and morbidity worldwide. There is a paucity of documented data on the prevalence of CQ-resistant mutant haplotypes of Pfcrt and Pfmdr1 genes from malaria-endemic war effected Federally Administered Tribal Areas of Pakistan. The objective of this study was to investigate the prevalence of $P$. falciparum CQ-resistance in this area. Clinical isolates were collected between May 2017 and May 2018 from North Waziristan and South Waziristan agencies of Federally Administrated Trial Area. Subsequently, Giemsa-stained blood smears were examined to detect Plasmodium falciparum. Extraction of malarial DNA was done from microscopy positive $P$. falciparum samples, and $P$. falciparum infections were confirmed by nested PCR (targeting Plasmodium small subunit ribosomal ribonucleic acid (ssrRNA) genes). All PCR confirmed $P$. falciparum samples were sequenced by pyrosequencing to find out mutation in Pfcrt gene at codon K76T and in pfmdr1 at codons N86Y, Y184F, N1042D, and D1246Y. Out of 121 microscopies positive P. falciparum cases, 109 samples were positive for $P$. falciparum by nested PCR. Pfcrt K76T mutation was found in $96 \%$ of isolates, Pfmdr1 N86Y mutation was observed in 20\%, and 11\% harboured Y184F mutation. All samples were wild type for Pfmdr1 codon N1042D and D1246Y. In the FATA, Pakistan, the frequency of resistant allele 76T remained high despite the removal of $\mathrm{CQ}$. However, current findings of the study suggest complete fixation of $P$. falciparum CQ-resistant genotype in the study area.
\end{abstract}

Keywords: chloroquine, Pakistan, Plasmodium falciparum, pfcrt gene, war-torn areas.

\begin{abstract}
Resumo
A resistência do Plasmodium falciparum à cloroquina (CQ)é uma causa significativa de mortalidade e morbidade em todo o mundo. Há uma escassez de dados documentados sobre a prevalência de haplótipos mutantes CQ-resistentes dos genes Pfcrt e Pfmdr1 da guerra endêmica da malária em áreas tribais administradas pelo governo federal do Paquistão. O objetivo deste estudo foi investigar a prevalência de resistência a CQ de $P$. falciparum nesta área. Isolados clínicos foram coletados entre maio de 2017 e maio de 2018 nas agências do Waziristão do Norte e do Waziristão do Sul da Área de Ensaio Administrada Federalmente. Posteriormente, esfregaços de sangue corados com Giemsa foram examinados para detectar Plasmodium falciparum. A extração do DNA da malária foi feita a partir de amostras de $P$. falciparum positivas para microscopia, e as infecções por $P$. falciparum foram confirmadas por nested PCR (visando genes de ácido ribonucleico ribossômico de subunidade pequena de Plasmodium (ssrRNA)). Todas as amostras de $P$. falciparum confirmadas por PCR foram sequenciadas por pirosequenciamento para descobrir a mutação no gene Pfcrt no códon K76T e em pfmdr1 nos códons N86Y, Y184F, N1042D e D1246Y. De 121 microscopias de casos positivos de P. falciparum, 109 amostras foram positivas para $P$. falciparum por nested PCR. A mutação Pfcrt K76T foi encontrada em 96\% dos isolados, a mutação Pfmdr1 N86Y foi observada em 20\% e 11\% abrigou a mutação Y184F. Todas as amostras eram do tipo selvagem para o códon N1042D e D1246Y de Pfmdr1. No FATA, Paquistão, a frequência do alelo resistente 76T permaneceu alta apesar da remoção de CQ. No entanto, as descobertas atuais do estudo sugerem a fixação completa do genótipo resistente a CQ de P. falciparum na área de estudo.
\end{abstract}

Palavras-chave: cloroquina; Paquistão; Plasmodium falciparum, gene pfcrt, áreas destruídas pela guerra.

*e-mail: amir.khattak@hotmail.com

Received: January 10, 2021 - Accepted: March 4, 2021

This is an Open Access article distributed under the terms of the Creative Commons Attribution License, which permits unrestricted use, distribution, and reproduction in any medium, provided the original work is properly cited. 


\section{Introduction}

Malaria still ranks as the third-highest morbidity and mortality, causing disease globally. About 3.2 billion peoples in 97 countries and territories are at risk of malaria. About 214 million malaria cases have been reported, with an estimated 0.4 million deaths mostly caused by P. falciparum. Malaria is the $6^{\text {th }}$ biggest threat of morbidity, and Pakistan's mortality could affect 205 million people, with 0.3 million cases each year (WHO, 2020; DMC, 2019; Khattak et al., 2013a). According to the World Health Organization (WHO), the Federally Administrated Tribal Area (FATA) is the second-highest malaria-endemic region (23\%) of Pakistan after Khyber Pakhtunkhwa (KP) province (31\%). However, FATA is on top of all provinces and territories regarding annual parasite incidence, blood examination, and test positivity rate (DMC, 2019).

Chloroquine (CQ) remained the standard treatment for $P$. falciparum malaria for more than five decades. In Pakistan, the first clinical case of CQ-resistance in P. falciparum was reported in 1984; however, many in vivo and in vitro CQ resistance reports are available (Bouma et al., 1996; Ghanchi et al., 2011; Khattak et al., 2013a, b; Rawasia et al., 2012; Yaqoob et al., 2018).

CQ resistance in $P$. falciparum results from mutations in two genes Plasmodium falciparum CQ-resistant transporter (Pfcrt) and Plasmodium falciparum multidrug resistance transporter 1 (Pfmdr1) gene. Both encode trans-membrane CQ transporter proteins present on the membrane of $P$. falciparum digestive vacuole. These transporter proteins are responsible for the transport and gathering of $\mathrm{CQ}$ in the parasite's food vacuole, which is the site for CQ action, while mutations in these genes alter the efflux of CQ from the intracellular digestive vacuole (Plowe, 2009; Vieira-Neta et al., 2021). Resistance to CQ is mediated by mutations at codons 72-76 (C72S/R, M74I/T, N75E/D/K/I, and $\mathrm{K} 76 \mathrm{~T} / \mathrm{I} / \mathrm{N})$ P. falciparum Pfcrt gene, results in amino acid substitutions from wild type CVMNK to two most prevalent mutant haplotypes CVIET and SVMNT present in African and South-East Asian countries respectively. These mutations have been associated with CQ reduced sensitivity; however, mutation at positive 76 with substitution of $\mathrm{K}$ with $\mathrm{T}$ is the key determinant mutation for in vitro (Fidock et al., 2000; Wellems and Plowe, 2001) and in vivo CQ-resistance (Djimde et al., 2001). Similarly, mutations at N86Y, Y184F, S1034C, N1042D, and D1246Y in the Pfmdr1 gene interfere with CQ transportation to food vacuole resulting in reduced CQ susceptibility to $P$. falciparum (Foote et al., 1990; Mallick et al., 2012; Petersen et al., 2011).

Khatoon et al. (2009) reported a significantly high CQ-resistance level in clinical isolates collected from Bannu (Khatoon et al., 2009). Complete fixation of K76T mutation has been reported by a comprehensive national molecular study conducted in fourteen cities of Pakistan (Khattak et al., 2013a). A study conducted during 2005-2007 in Karachi revealed Pfcrt 76T mutation in 93\% and Pfmdr1 $86 \mathrm{Y}$ in $57 \%$ of samples.
The current study is designed to investigate CQ-resistance patterns based on Pfcrt-76T and Pfmdr1 N86Y/Y184F markers among $P$. falciparum isolates collected from North and South Waziristan agencies of FATA, KP.

\section{Methods}

\subsection{Study locations and ethics}

FATA is a mountainous region of northwest Pakistan, bordering Afghanistan. Unrest and political destabilization in this region had destroyed public health infrastructure and health care system leading to the emergence of different infectious and vector-borne diseases like malaria. This study's objective is to check the pattern of CQ-resistance in P. falciparum from malaria symptomatic patients between May 2017 and May 2018, irrespective of age and gender. About $5 \mathrm{~mL}$ of anti-coagulated blood was collected by the venipuncture technique after taking proper consent from parents/guardians. The exclusion criteria were non-consent and other species of Plasmodium. The study was approved by the Advanced Studies and the Research Board University of Gujrat, Pakistan.

\subsection{Sample collection and microscopy}

About $5 \mathrm{~mL}$ of anti-coagulated venous blood specimen was collected from malaria symptomatic patients. Thin and thick blood smears were prepared and stained with $10 \%$ Giemsa stain. Smears were examined under 1000X magnification of light microscope by trained microscopist, and remaining blood specimen was stored in $-20{ }^{\circ} \mathrm{C}$ for molecular drug resistance analysis.

\subsection{DNA extraction and speciation}

Parasitic DNA was extracted from 121 microscopy confirmed $P$. falciparum positive samples using DNA mini kit (Qiagen) using blood samples according to the manufacturer instructions. P. falciparum specie was reconfirmed by two rounds of nested polymerase chain reaction (nPCR). Amplification of Plasmodium (genus) DNA was done in the primary round nPCR using genus-specific primers and speciation in the second round of nPCR. Published Primers, ingredients concentration, and thermal cycler conditions were used (Snounou et al., 1993; Soares-Pinheiro et al., 2017). Nested PCR of 121 samples confirmed 109 samples positive for $P$. falciparum; 4 were with mixed-species infection, and the rest were not amplifiable. MR4 clones MRA-340G, MRA-343G, 3D7, and HB3, were used as positive, whereas sterile water was used as a negative control, as shown in Figure 1.

\subsection{Pyrosequencing of Pfcrt and Pfmdr1 genes}

Previously published pyrosequencing protocol was used to analyze CQ resistance mutations in Pfcrt and Pfmdr1 genes of $P$. falciparum (Khattak et al., 2013a). The amplified product was resolved on QIAxcel capillary electrophoresis (Qiagen) with a 50 bp DNA ladder, as shown in Figure 2. 


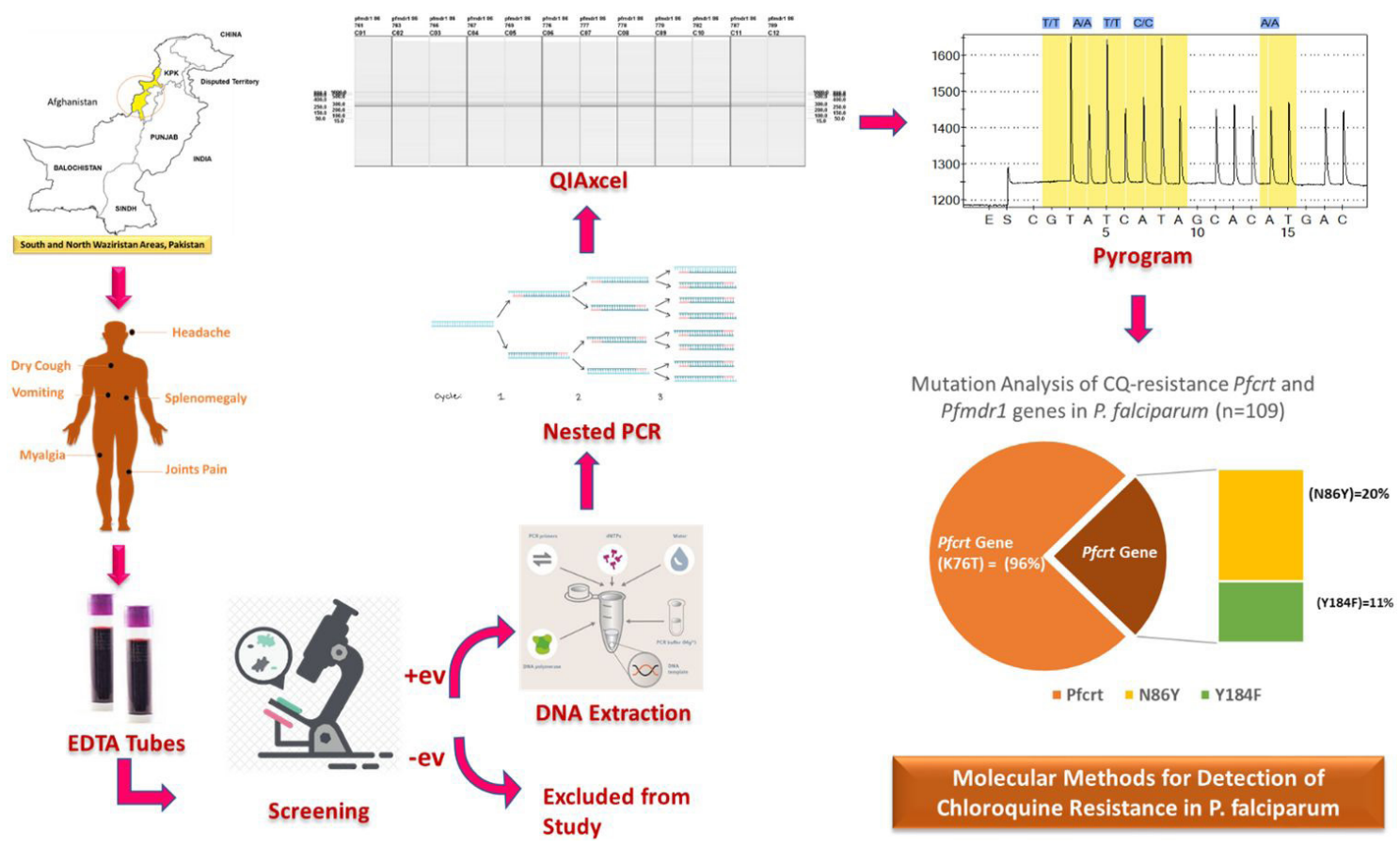

Figure 1. Stepwise flow chart for the detection of Chloroquine Resistance in the Plasmodium falciparum species.

(a)

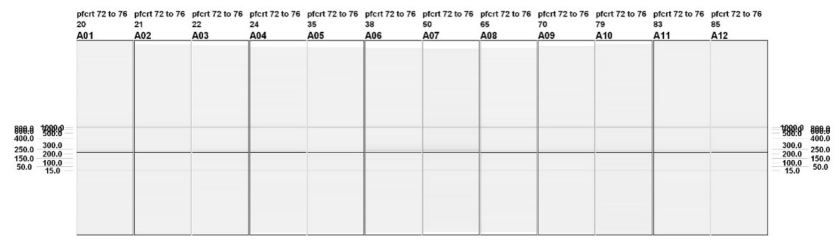

(b)

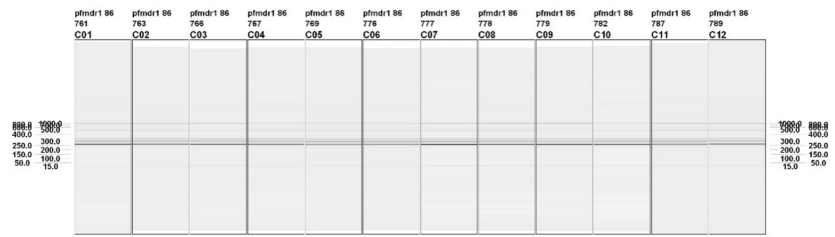

(c)

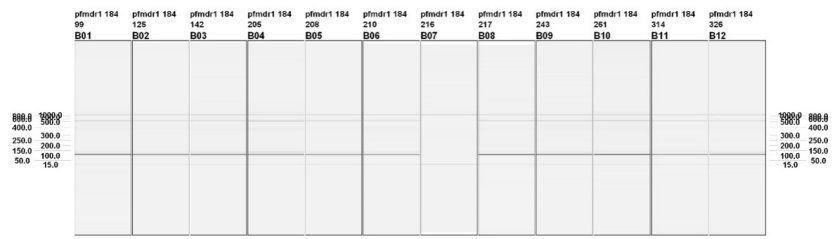

(d)

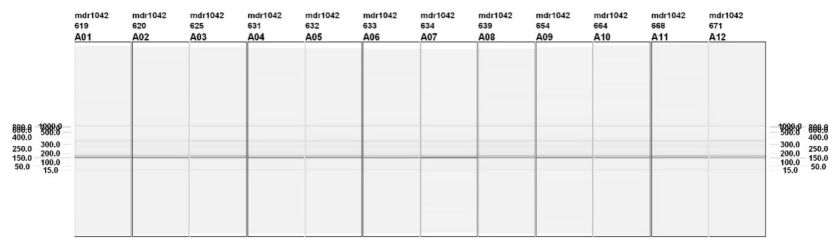

Figure 2. QIAxcel capillary electrophoresis of pfcrt codons 72-76 (a), pfmdr1 codons N86Y (b), Y184F (c), and S1034C (d) containing gene fragments. 


\section{Results}

A total of 121 microscopy confirmed P. falciparum clinical isolates were collected from North and South Waziristan agencies of FATA, KP. Nested PCR revealed $109 P$. falciparum microscopy positive samples, and 04 samples were mixed for $P$. falciparum plus $P$. vivax, and the rest were not amplifiable. Mixed species and negative isolates were excluded from the study after the re-extraction of DNA and re-amplification (Figure 3). All 109 P. falciparum positive samples were analyzed for drug resistance polymorphism in Pfcrt and Pfmdr1. CQ coffering drug resistance mutation K76T was found in 105 (96\%) samples. This mutation in the Pfcrt gene is associated with reduced CQ sensitivity in P. falciparum (Bray et al., 2005; Fidock et al., 2000), as shown in Figure 4. In N86Y, a mutant allele was found in $22(20 \%)$, and 12 (11\%) isolates harbored Y184F mutation. Not a single sample showed Pfmdr1 S1034C and N1042D mutation, as shown in Table 1.

\section{Discussion}

This is the first molecular assessment of $P$. falciparum CQ-resistance in this war-affected North and South Waziristan agencies of FATA Pakistan. In earlier 2008, CQ and SP were the only choice of drugs for malaria treatment in Pakistan, after the anti-malarial drug policy for uncomplicated $P$. falciparum was changed to (AS+SP) (artesunate plus sulphadoxine-pyrimethamine). However, the use of CQ as mono-therapy is still there in many health care setups (Ghanchi et al., 2011; Khattak et al., 2013a; Koenderink et al., 2010).

Pfcrt K76T mutation associated with CQ resistance was found in $96 \%$ of isolates, and similar findings have been reported in other studies (Khan et al., 2020; Yaqoob et al., 2018; Khattak et al., 2013a; Khatoon et al., 2009). Pfcrt K76T mutation and SVMNT haplotype in all samples are in accordance with results reported on samples collected from Pakistan, India, Iran, and Saudi Arabia (Ocan et al., 2019; Zomuanpuii et al., 2020; Khan et al., 2020; Bin Dajem and Al-Qahtani, 2010) Studies from Papua New Guinea and South American also reported SVMNT haplotype that was found in our isolates, whereas CVIET haplotype is more prevalent in Asia/Africa (Yang et al., 2007; Wootton et al.,
2002) Pfcrt K76T mutation and SVMNT haplotype had been associated with CQ resistance (Plowe, 2009).

These findings indicate complete fixation of CQ-resistance in P. falciparum is might possibility because of very high CQ-resistance in Pakistan could be due to the co-existence of $P$. falciparum with $P$. vivax infections, and CQ is the recommended anti-malarial treatment for P. vivax malaria treatment (WHO, 2020, Mallmann et al., 2018). Misdiagnosis of co-infection by conventional light microscopy is widespread in resource-limited areas (Mayxay et al., 2001). Different studies have reported mixed species malaria infections in Pakistan (Khatoon et al., 2009; Khattak et al., 2013b).

Many studies have uncovered the role of the mdr1 gene family in modulating the sensitivity of different anti-malarial, including CQ (Duraisingh et al., 1997; Price et al., 2004; Wilson et al., 1993; Warhurst, 2001). Mutations in pfmdr1 and pfcrt genes have been associated with malarial infection severity as reports from India, the Gambia, Iranian, Angola, Tanzania, and eastern Sudan (Vathsala et al., 2004; Figueiredo et al., 2008; Khalil et al., 2005; Meerman et al., 2005; Zakeri et al., 2008). Mutations that further increase CQ-resistance are N86Y and Y184F; these were observed in $15 \%$ and $7 \%$ isolates, respectively. Isolates carrying wild type and mutant allele were counted as mutant.

Our results are similar to the studies carried out in Pakistani, Iranian, and Indianan isolates (Khatoon et al., 2009; Pathak et al., 2014; Jalousian et al., 2008). Few mutations in the Pfmdr1 gene and its single copy suggest

Table 1. Number (N) and Percentage (\%) of Pfcrt and Pfmdr1, mutant alleles associated with CQ-resistance in P. falciparum.

\begin{tabular}{cccc}
\hline \multicolumn{4}{c}{$\begin{array}{c}\text { Mutation Analysis of CQ-resistance Pfcrt and Pfmdr1 } \\
\text { genes in P. falciparum (n=109) }\end{array}$} \\
\hline Gene & Codons & (n) & $\%$ \\
\hline Pfcrt & K76T & 105 & 96 \\
Pfmdr1 & N86Y & 22 & 20 \\
& Y184F & 12 & 11 \\
& S1034C & 0 & 0 \\
& N1042D & 0 & 0 \\
\hline
\end{tabular}

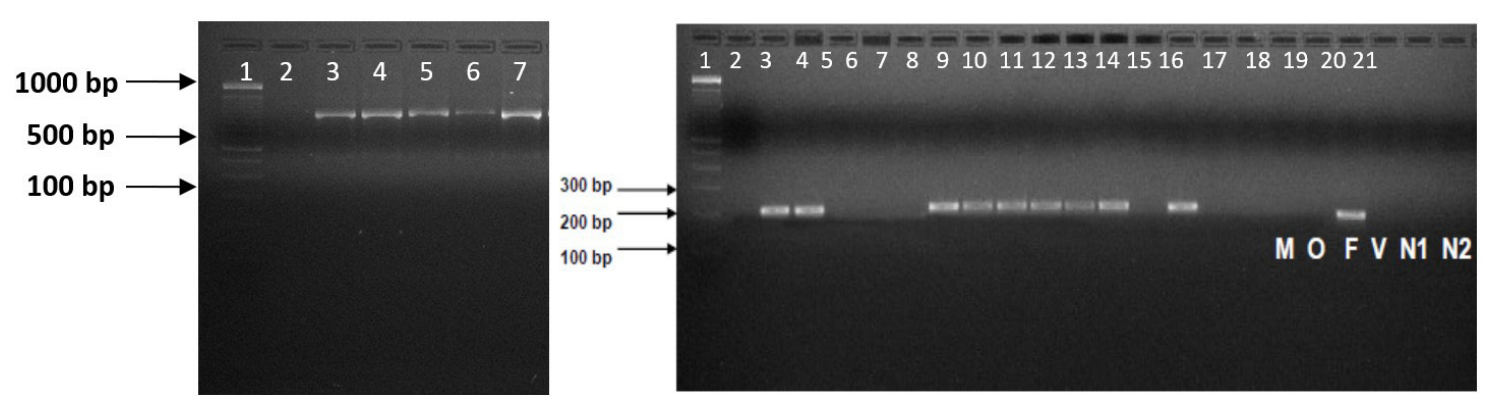

Figure 3. Product of the second round of nested PCR showing Plasmodium falciparum bands ( $205 \mathrm{bp}$ ) on agarose gel against $100 \mathrm{bp}$ DNA ladder (lane no 1). M: P. malariae (control), O: P. ovale (control), F: P. falciparum, V: P. vivax (control), N1-N2: Negative Controls. 


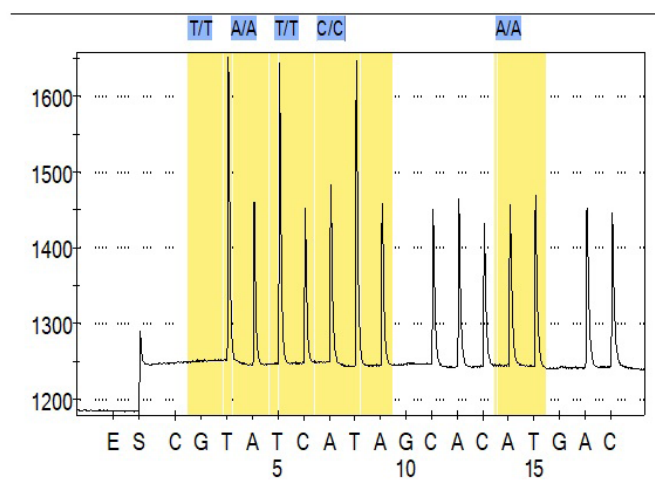

(a) Pfcrt 72-76 wild type

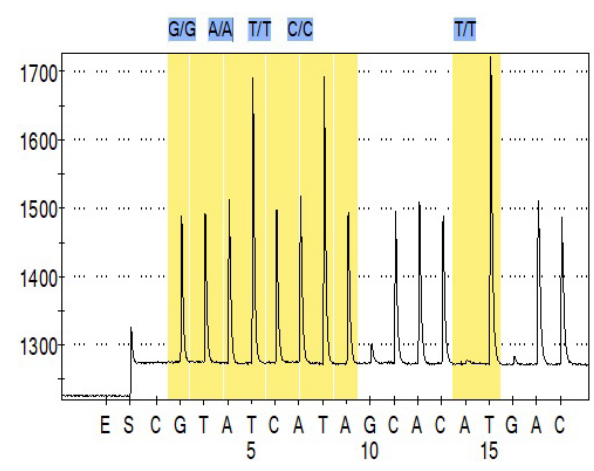

(b) Pfcrt 72-76 wild type

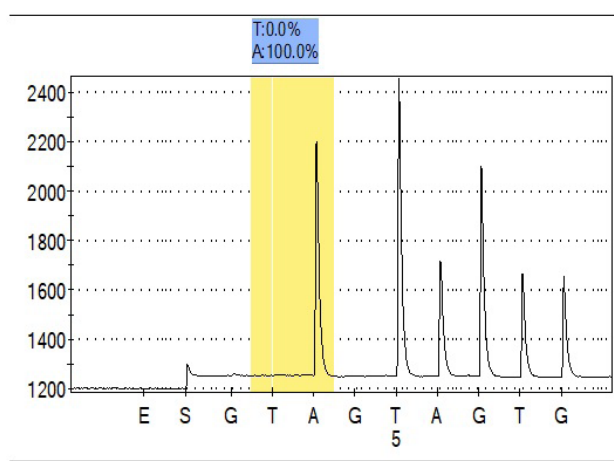

(c) Wild pfmdr1 codon N86Y

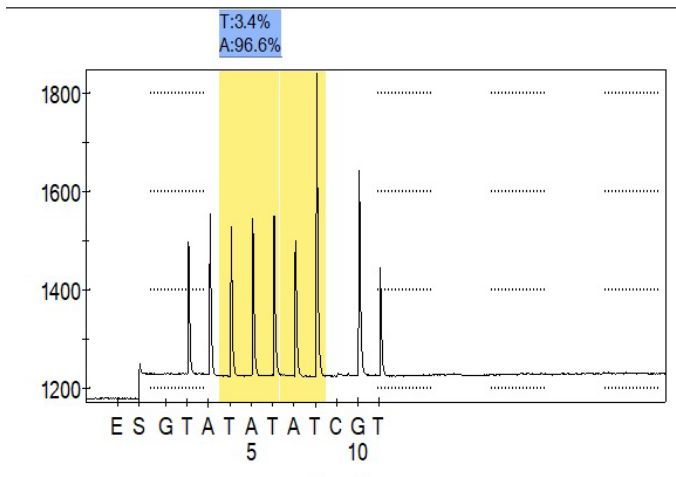

(e) Wild pfmdr1 codon Y184F

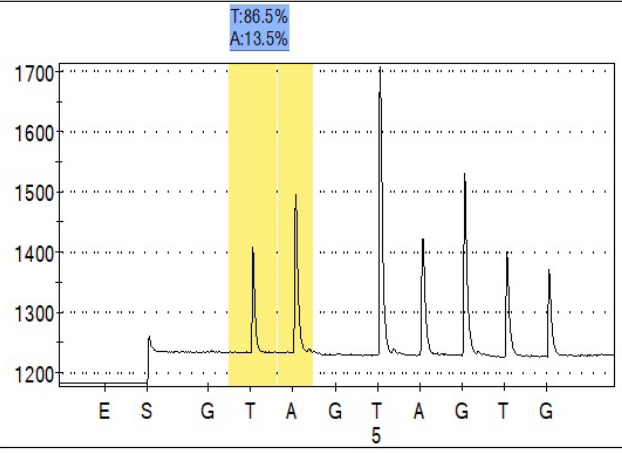

(d) Mutant pfmdr1 codon N86Y

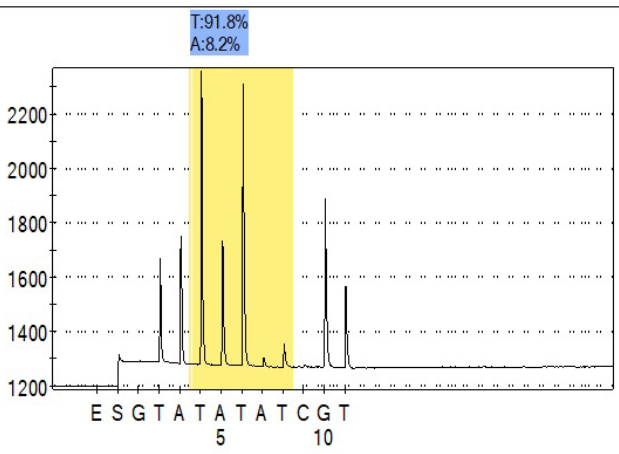

(f) Mutant pfmdr1 codon Y184F

Figure 4. Pyrosequencing graphs representing for pfcrt codons 72-76, pfmdr1 codons N86Y, Y184F, and S1034C wild-type and mutanttype patient samples.

that artesunate and (AS+SP) partner drugs such as mefloquine and lumefantrine are likely to have high efficacy in Pakistan. The presence of Pfmdr1 mutations at codons N86Y and Y184F of Pfmdr1 and Pfcrt mutation at K76T leads to an elevated level of CQ-resistance as investigated previously (Mayengue et al., 2007; Babiker et al., 2001; Reed et al., 2000). Warhurst (2001) believed that the Pfcrt gene mutation imparts a basic level of CQ-resistance; however, an additive effect in CQ resistance is observed with Pfmdr1 mutations.

\section{Conclusion}

Execution of complete withdrawal of CQ drug after WHO anti-malarial policy revised was not fully adopted; thus, its continued access and use could have contributed to the persistence of CQ resistance alleles in this region. As K76T pfcrt mutation has been fixed in P. falciparum so proper Plasmodium species detection should be done, CQ for uncomplicated $P$. falciparum malaria should be used strongly be discouraged as it is a first-line treatment for $P$. 
vivax in Pakistan. This phenomenon is due to continuous exposure to drug pressure. Still today, some clinicians in government/private hospitals have provided CQ for the treatment of $P$. falciparum malaria cases in FATA and certain parts of the country. It needs to be released and should focus on the newly introduced (AS+SP) for the treatment of P. falciparum malaria cases.

\section{Acknowledgements}

We thank the study participants for their involvement in the study and the anonymous reviewer for comments that substantially improved the manuscript.

This study was obtained from the Institutional Review Board of the University of Gujrat, Pakistan. After explaining the study's purpose, informed consent was taken from all patients or guardians in case of patient's age less than 18 years.

\section{References}

BABIKER, H.A., PRINGLE, S., ABDEL-MUHSIN, A., MACKINNON, M., HUNT, P. and WALLIKER, D., 2001. High-level chloroquine resistance in Sudanese isolates of Plasmodium falciparum is associated with mutations in the chloroquine resistance transporter gene pfcrt and the multidrug resistance Gene pfmdr1. The Journal of Infectious Diseases, vol. 183, no. 10, pp. 1535-1538. http://dx.doi.org/10.1086/320195. PMid:11319692.

BIN DAJEM, S.M. and AL-QAHTANI, A., 2010. Analysis of gene mutations involved in chloroquine resistance in Plasmodium falciparum parasites isolated from patients in the southwest of Saudi Arabia. Annals of Saudi Medicine, vol. 30, no. 3, pp. 187-192. http://dx.doi.org/10.4103/0256-4947.62826. PMid:20427933.

BOUMA, M., DYE, C. and VAN DER KAAY, H., 1996. Falciparum malaria and climate change in the northwest frontier province of Pakistan. The American Journal of Tropical Medicine and Hygiene, vol. 55, no. 2, pp. 131-137. http://dx.doi.org/10.4269/ ajtmh.1996.55.131. PMid:8780449.

BRAY, P.G., MARTIN, R.E., TILLEY, L., WARD, S.A., KIRK, K. and FIDOCK, D.A., 2005. Defining the role of PfCRT in Plasmodium falciparum chloroquine resistance. Molecular Microbiology, vol. 56, no. 2, pp. 323-333. http://dx.doi.org/10.1111/j.13652958.2005.04556.x. PMid:15813727.

DIRECTORATE OF MALARIA CONTROL - DMC, 2019 [viewed 20 January 2021]. Pakistan Malaria annual report 2019 [online]. Pakistan. Available from: http://dmc.gov.pk/docum ents/ pdfs/Pakis tan\%20Mal aria\%20Ann ual\%20 Rep ort\%20201 9\%20(002).pdf

DJIMDE, A., DOUMBO, O.K., CORTESE, J.F., KAYENTAO, K., DOUMBO, S., DIOURTÉ, Y., COULIBALY, D., DICKO, A., SU, X.-Z., NOMURA, T., FIDOCK, D.A., WELLEMS, T.E. and PLOWE, C.V., 2001. A molecular marker for chloroquine-resistant falciparum malaria. The New England Journal of Medicine, vol. 344, no. 4, pp. 257-263. http:// dx.doi.org/10.1056/NEJM200101253440403. PMid:11172152.

DURAISINGH, M., DRAKELEY, C., MULLER, O., BAILEY, R., SNOUNOU, G., TARGETT, G., GREENWOOD, B. and WARHURST, D., 1997. Evidence for selection for the tyrosine-86 allele of the pfmdr 1 gene of Plasmodium falciparum by chloroquine and amodiaquine. Parasitology, vol. 114, no. 3, pp. 205-211. http:// dx.doi.org/10.1017/S0031182096008487. PMid:9075340.
FIDOCK, D.A., NOMURA, T., TALLEY, A.K., COOPER, R.A., DZEKUNOV, S.M., FERDIG, M.T., URSOS, L.M.B., BIR SINGH SIDHU, A., NAUDÉ, B., DEITSCH, K.W., SU, X., WOOTTON, J.C., ROEPE, P.D. and WELLEMS, T.E., 2000. Mutations in the P. falciparum digestive vacuole transmembrane protein PfCRT and evidence for their role in chloroquine resistance. Molecular Cell, vol. 6, no. 4, pp. 861-871. http://dx.doi.org/10.1016/S1097-2765(05)00077-8. PMid: 11090624.

FIGUEIREDO, P., BENCHIMOL, C., LOPES, D., BERNARDINO, L., DO ROSÁRIO, V.E., VARANDAS, L. and NOGUEIRA, F., 2008. Prevalence of pfmdr1, pfcrt, pfdhfr and pfdhps mutations associated with drug resistance, in Luanda, Angola. Malaria Journal, vol. 7, no. 1, pp. 236. http://dx.doi.org/10.1186/1475-2875-7-236. PMid:19014684.

FOOTE, S., KYLE, D., MARTIN, R., ODUOLA, A., FORSYTH, K., KEMP, D. and COWMAN, A., 1990. Several alleles of the multidrugresistance gene are closely linked to chloroquine resistance in Plasmodium falciparum. Nature, vol. 345, no. 6272, pp. 255-258. http://dx.doi.org/10.1038/345255a0. PMid:2185424.

GHANCHI, N.K., URSING, J., BEG, M.A., VEIGA, M.I., JAFRI, S. and MÅRTENSSON, A., 2011. Prevalence of resistance associated polymorphisms in Plasmodium falciparum field isolates from southern Pakistan. Malaria Journal, vol. 10, no. 1, pp. 18. http:// dx.doi.org/10.1186/1475-2875-10-18. PMid:21272384.

JALOUSIAN, F., DALIMI, A., SAMIEE, S.M., GHAFFARIFAR, F., SOLEYMANLOO, F. and NAGHIZADEH, R., 2008. Mutation in pfmdr1 gene in chloroquine-resistant Plasmodium falciparum isolates, Southeast Iran. International Journal of Infectious Diseases, vol. 12, no. 6, pp. 630-634. http://dx.doi.org/10.1016/j. ijid.2008.01.004. PMid:18926753.

KHALIL, I., ALIFRANGIS, M., TARIMO, D., STAALSØ, T., SATTI, G., THEANDER, T., RØNN, A. and BYGBJERG, I., 2005. The roles of the pfcrt $76 \mathrm{~T}$ and pfmdr1 $86 \mathrm{Y}$ mutations, immunity and the initial level of parasitaemia, in predicting the outcome of chloroquine treatment in two areas with different transmission intensities. Annals of Tropical Medicine and Parasitology, vol. 99, no. 5, pp. 441-448. http://dx.doi.org/10.1179/136485905X46441. PMid:16004703.

KHAN, A.Q., PERNAUTE-LAU, L., KHATTAK, A.A., LUIJCX, S., AYDIN-SCHMIDT, B., HUSSAIN, M., KHAN, T.A., MUFTI, F.U. and MORRIS, U., 2020. Surveillance of genetic markers associated with Plasmodium falciparum resistance to artemisinin-based combination therapy in Pakistan, 2018-2019. Malaria Journal, vol. 19, no. 1, pp. 206. http://dx.doi.org/10.1186/s12936-02003276-8. PMid:32513171.

KHATOON, L., MALIK, S.A., BONIZZONI, M., BALIRAINE, F.N. and YAN, G., 2009. Prevalence of antimalarial drug resistance mutations in Plasmodium vivax and $P$. falciparum from a malaria-endemic area of Pakistan. The American Journal of Tropical Medicine and Hygiene, vol. 81, no. 3, pp. 525-528. http://dx.doi.org/10.4269/ ajtmh.2009.81.525. PMid:19706926.

KHATTAK, A.A., VENKATESAN, M., JACOB, C.G., ARTIMOVICH, E.M., NADEEM, M.F., NIGHAT, F., HOMBHANJE, F., MITA, T., MALIK, S.A. and PLOWE, C.V., 2013a. A comprehensive survey of polymorphisms conferring anti-malarial resistance in Plasmodium falciparum across Pakistan. Malaria Journal, vol. 12, no. 1, pp. 300. http://dx.doi.org/10.1186/1475-2875-12-300. PMid:23988011.

KHATTAK, A.A., VENKATESAN, M., KHATOON, L., OUATTARA, A., KENEFIC, L.J., NADEEM, M.F., NIGHAT, F., MALIK, S.A. and PLOWE, C.V., 2013b. Prevalence and patterns of antifolate and chloroquine drug resistance markers in Plasmodium vivax across Pakistan. Malaria Journal, vol. 12, no. 1, pp. 310. http://dx.doi. org/10.1186/1475-2875-12-310. PMid:24007534. 
KOENDERINK, J.B., KAVISHE, R.A., RIJPMA, S.R. and RUSSEL, F.G., 2010. The ABCs of multidrug resistance in malaria. Trends in Parasitology, vol. 26, no. 9, pp. 440-446. http://dx.doi. org/10.1016/j.pt.2010.05.002. PMid:20541973.

MALLICK, P.K., JOSHI, H., VALECHA, N., SHARMA, S.K., EAPEN, A., BHATT, R.M., SRIVASTAVA, H.C., SUTTON, P.L., DASH, A.P. and BHASIN, V.K., 2012. Mutant pfcrt "SVMNT" haplotype and wild type pfmdr1 "N86" are endemic in Plasmodium vivax dominated areas of India under high chloroquine exposure. Malaria Journal, vol. 11, no. 1, pp. 16. http://dx.doi.org/10.1186/1475-2875-1116. PMid:22236376.

MALLMANN, R., ETHUR, E., BIANCHETTI, P., FALEIRO, D., HOEHNE, L. and GOETTERT, M., 2018. Effectiveness of aqueous and hydroalcoholic extracts of Acanthospermum australe (Loefl.) Kuntze against diarrhea-inducing bacteria. Brazilian Journal of Biology = Revista Brasileira de Biologia, vol. 78, no. 4, pp. 619-624 http://dx.doi.org/10.1590/1519-6984.167376. PMid:29319752.

MAYENGUE, P.I., KALMBACH, Y., ISSIFOU, S., KREMSNER, P.G. and NTOUMI, F., 2007. No variation in the prevalence of point mutations in the Pfcrt and Pfmdr1 genes in isolates from Gabonese patients with uncomplicated or severe Plasmodium falciparum malaria. Parasitology Research, vol. 100, no. 3, pp. 487-493. http://dx.doi.org/10.1007/s00436-006-0287-8. PMid:17096149.

MAYXAY, M., WHITE, N.J., LOOAREESUWAN, S., PUKRITRAYAKAMEE, S., CHOTIVANICH, K. and IMWONG, M., 2001. Identification of cryptic coinfection with Plasmodium falciparum in patients presenting with vivax malaria. The American Journal of Tropical Medicine and Hygiene, vol. 65, no. 5, pp. 588-592. http://dx.doi. org/10.4269/ajtmh.2001.65.588. PMid:11716119.

MEERMAN, L., ORD, R., BOUSEMA, J.T., VAN NIEKERK, M., OSMAN, E., HALLETT, R., PINDER, M., WALRAVEN, G. and SUTHERLAND, C.J., 2005. Carriage of chloroquine resistant parasites and delay of effective treatment increase the risk of severe malaria in gambian children. The Journal of Infectious Diseases, vol. 192, no. 9, pp. 1651-1657. http://dx.doi.org/10.1086/496887.

OCAN, M., AKENA, D., NSOBYA, S., KAMYA, M.R., SENONO, R., KINENGYERE, A.A. and OBUKU, E.A., 2019. Persistence of chloroquine resistance alleles in malaria endemic countries: a systematic review of burden and risk factors. Malaria Journal, vol. 18, no. 1, pp. 76. http://dx.doi.org/10.1186/s12936-0192716-z. PMid:30871535.

PATHAK, A., MÅRTENSSON, A., GAWARIKER, S., MANDLIYA, J., SHARMA, A., DIWAN, V. and URSING, J., 2014. Characterization of drug resistance associated genetic polymorphisms among Plasmodium falciparum field isolates in Ujjain, Madhya Pradesh, India. Malaria Journal, vol. 13, no. 1, pp. 182. http://dx.doi. org/10.1186/1475-2875-13-182. PMid:24885535.

PETERSEN, T.N., BRUNAK, S., VON HEIJNE, G. and NIELSEN, H., 2011. SignalP 4.0: discriminating signal peptides from transmembrane regions. Nature Methods, vol. 8, no. 10, pp. 785-786. http:// dx.doi.org/10.1038/nmeth.1701. PMid:21959131.

PLOWE, C.V., 2009. The evolution of drug-resistant malaria. Transactions of the Royal Society of Tropical Medicine and Hygiene, vol. 103, no. 1, pp. S11-S14. http://dx.doi.org/10.1016/j. trstmh.2008.11.002.

PRICE, R.N., UHLEMANN, A.-C., BROCKMAN, A., MCGREADY, R., ASHLEY, E., PHAIPUN, L., PATEL, R., LAING, K., LOOAREESUWAN, S., WHITE, N.J., NOSTEN, F. and KRISHNA, S., 2004. Mefloquine resistance in Plasmodium falciparum and increased pfmdr1 gene copy number. Lancet, vol. 364, no. 9432, pp. 438-447. http:// dx.doi.org/10.1016/S0140-6736(04)16767-6. PMid:15288742.

RAWASIA, W.F., SRIDARAN, S., PATEL, J.C., ABDALLAH, J., GHANCHI, N.K., BARNWELL, J.W., ESCALANTE, A.A., UDHAYAKUMAR, V. and BEG, M.A., 2012. Genetic backgrounds of the Plasmodium falciparum chloroquine resistant transporter (pfcrt) alleles in Pakistan. Infection, Genetics and Evolution, vol. 12, no. 2, pp. 278-281. http://dx.doi.org/10.1016/j.meegid.2011.11.008. PMid:22138496.

REED, M.B., SALIBA, K.J., CARUANA, S.R., KIRK, K. and COWMAN, A.F., 2000. Pgh1 modulates sensitivity and resistance to multiple antimalarials in Plasmodium falciparum. Nature, vol. 403, no. 6772, pp. 906-909. http://dx.doi.org/10.1038/35002615. PMid:10706290.

SNOUNOU, G., VIRIYAKOSOL, S., ZHU, X.P., JARRA, W., PINHEIRO, L., DO ROSARIO, V.E., THAITHONG, S. and BROWN, K.N., 1993. High sensitivity of detection of human malaria parasites by the use of nested polymerase chain reaction. Molecular and Biochemical Parasitology, vol. 61, no. 2, pp. 315-320. PMid:8264734.

SOARES-PINHEIRO, V.C., DASSO-PINHEIRO, W., TRINDADE-BEZERRA, J. and TADEI, W.P., 2017. Eggs viability of Aedes aegypti Linnaeus (Diptera, Culicidae) under different environmental and storage conditions in Manaus, Amazonas, Brazil. Brazilian Journal of Biology = Revista Brasileira de Biologia, vol. 77, no. 2, pp. 396-401. http://dx.doi.org/10.1590/1519-6984.19815. PMid:27533732.

VATHSALA, P.G., RANGARAJAN, P.N., MISHRA, G.C., DHANASEKARAN, S., TIWARI, S.N., DASH, A.P., PILLAI, C.R., PRAMANIK, A., DESHPANDE, P.R., PADMANABAN, G., GHOSH, S.K., DEVI, C.U., SATHYANARAYAN, T.S., RANJIT, M.R. and SUBBARAO, S.K., 2004. Widespread occurrence of the Plasmodium falciparum chloroquine resistance transporter (Pfcrt) gene haplotype SVMNT in P. falciparum malaria in India. The American Journal of Tropical Medicine and Hygiene, vol. 70, no. 3, pp. 256-259. http://dx.doi.org/10.4269/ajtmh.2004.70.256. PMid:15031513.

VIEIRA-NETA, M., SOARES-DA-SILVA, J., VIANA, J., SILVA, M., TADEI, W. and PINHEIRO, V., 2021. Strain of Bacillus thuringiensis from Restinga, toxic to Aedes (Stegomyia) aegypti (Linnaeus) (Diptera, Culicidae). Brazilian Journal of Biology $=$ Revista Brasileira de Biologia, vol. 81, no. 4, pp. 872-880. http://dx.doi. org/10.1590/1519-6984.228790.

WARHURST, D.C., 2001. A molecular marker for chloroquineresistant falciparum malaria. The New England Journal of Medicine, vol. 344, no. 4, pp. 299-302. http://dx.doi.org/10.1056/ NEJM200101253440411. PMid:11172160.

WELLEMS, T.E. and PLOWE, C.V., 2001. Chloroquine-resistant malaria. The Journal of Infectious Diseases, vol. 184, no. 6, pp. 770-776. http://dx.doi.org/10.1086/322858. PMid:11517439.

WILSON, C.M., VOLKMAN, S.K., THAITHONG, S., MARTIN, R.K., KYLE, D.E., MILHOUS, W.K. and WIRTH, D.F., 1993. Amplification of pfmdr1 associated with mefloquine and halofantrine resistance in Plasmodium falciparum from Thailand. Molecular and Biochemical Parasitology, vol. 57, no. 1, pp. 151-160. http:// dx.doi.org/10.1016/0166-6851(93)90252-S. PMid:8426608.

WOOTTON, J.C., FENG, X., FERDIG, M.T., COOPER, R.A., MU, J., BARUCH, D.I., MAGILL, A.J. and SU, X.-Z., 2002. Genetic diversity and chloroquine selective sweeps in Plasmodium falciparum. Nature, vol. 418, no. 6895, pp.320-323. http://dx.doi.org/10.1038/ nature00813. PMid:12124623.

WORLD HEALTH ORGANIZATION - WHO, 2020 [viewed 20 February 2021]. World malaria report 2019 [online]. Geneva: WHO. Available from: https://www.who.int/publications/i/ item/9789241565721

YANG, Z., ZHANG, Z., SUN, X., WAN, W., CUI, L., ZHANG, X., ZHONG, D., YAN, G. and CUI, L., 2007. Molecular analysis of chloroquine resistance in Plasmodium falciparum in Yunnan Province, China. Tropical Medicine E International Health, vol. 12, no. 9, pp. 1051-1060. http://dx.doi.org/10.1111/j.1365-3156.2007.01882.x. PMid:17875016. 
YAQOOB, A., KHATTAK, A.A., NADEEM, M.F., FATIMA, H., MBAMBO, G., OUATTARA, A., ADAMS, M., ZEESHAN, N. and TAKALAHARRISON, S., 2018. Prevalence of molecular markers of sulfadoxine-pyrimethamine and artemisinin resistance in Plasmodium falciparum from Pakistan. Malaria Journal, vol. 17, no. 1, pp. 471. http://dx.doi.org/10.1186/s12936-018-2620-y. PMid:30558587.

ZAKERI, S., DJADID, N.D., MEHDIZADEH, K., SHABANI, A., KAZEMZADEH, T. and AFSHARPAD, M., 2008. Association of pfcrt but not pfmdr1 alleles with chloroquine resistance in Iranian isolates of Plasmodium falciparum. The American Journal of Tropical Medicine and Hygiene, vol. 78, no. 4, pp. 633-640. http://dx.doi.org/10.4269/ajtmh.2008.78.633. PMid:18385361.

ZOMUANPUII, R., HMAR, C.L., LALLAWMZUALA, K., HLIMPUIA, L., BALABASKARAN NINA, P. and SENTHIL KUMAR, N., 2020. Epidemiology of malaria and chloroquine resistance in Mizoram, northeastern India, a malaria-endemic region bordering Myanmar. Malaria Journal, vol. 19, no. 1, pp. 95. http://dx.doi. org/10.1186/s12936-020-03170-3. PMid:32103751. 